\title{
Razdvajanje protočnim poljem u analizi kompleksnih bioloških uzoraka
}

\author{
I. Mijić, ${ }^{a}$ J. Madunić, ${ }^{b^{*}}$ S. Marinc ${ }^{\mathrm{c}}$ i M. Cindrića \\ a Zavod za molekularnu medicinu, Institut Ruđer Bošković, Bijenička cesta 54, 10000 Zagreb

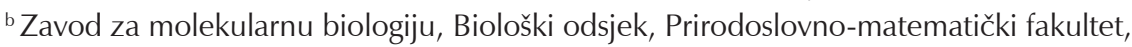 \\ Sveučilište u Zagrebu, Horvatovac 102a, 10000 Zagreb \\ c Kvaliteta, Hospira Zagreb d. o. o., Prilaz baruna Filipovića 29d, 10000 Zagreb
}

\begin{abstract}
Pregledom su objašnjeni način rada i principi razdvajanja čestica tehnikom razdvajanja protočnim poljem. Opisana je podjela ove tehnike s obzirom na svojstva analiziranih čestica i primijenjeno vanjsko polje na sedimentacijsku, protočnu, termičku, električnu i magnetsku. Pri tome su za svaku od navedenih tehnika razdvajanja protočnim poljem navedene prednosti, nedostatci i područja primjene. $U$ ovom je radu naveden niz primjera uspješne primjene opisane tehnike. Također su navedeni načini sprezanja tehnika razdvajanja protočnim poljem s jednostavnijim i sa složenijim sustavima detekcije, kao što su detekcija ultraljubičasto-vidljivim spektrom, detekcija višekutnim svjetlosnim raspršenjem ili tehnike spektrometrije masa, pri čemu je na primjerima objašnjena njihova uspješna primjena u analizi kompleksnih bioloških uzoraka.
\end{abstract}

Ključne riječi: Tehnika razdvajanja protočnim poljem, analitičke tehnike, razdvajanje čestica

\section{Uvod}

Analize kompleksnih uzoraka, koji se sastoje od čestica u rasponu veličina od nekoliko nanometara pa sve do nekoliko desetaka mikrometara, stavljaju pred izazov današnje rutinske analitičke metode. U kasnim 1960-im godinama ${ }^{1}$ postavljeni su temelji nove analitičke tehnike koja ima sposobnost razdvajanja čestica u tom rasponu. Ta tehnika, tzv. tehnika razdvajanja protočnim poljem (engl. Field-flow Fractionation, FFF) ponajprije se primjenjivala za razdvajanje većih čestica kao što su makromolekule i koloidi. Napredak tehnologije te razvoj i usavršavanje tehnike razdvajanja protočnim poljem doveo je do njezina sprezanja s dobro razvijenim, specifičnim i vrlo osjetljivim analitičkim metodama, pri čemu je tehnika FFF postala neizostavna pri izolaciji, separaciji i analizi različitih kompleksnih uzoraka kao što su polimeri, prašci, emulzije, koloidi, geološki sedimenti, biopolimeri, biočestice, kompleksni proteini, micele, polisaharidi, sintetski polimeri itd. Ta je tehnika posebno važna $u$ različitim biotehnološkim procesima i tehnologijama proizvodnje novih nanomaterijala jer nastaju vrlo složeni uzorci različitih molekulskih masa, veličina, oblika, naboja, stupnjeva grananja ili mikrostruktura, koje je današnjim analitičkim metodama vrlo teško karakterizirati.

\section{Principi razdvajanja}

Razdvajanje protočnim poljem je separacijska tehnika koja se zasniva na razdvajanju čestica prema njihovoj veličini, odnosno brzini kretanja opisanoj Brownovim gibanjem. ${ }^{2}$ Tehnika FFF ima jedinstvenu sposobnost da s visokom razlučivošću razdvaja čestice preko cijelog koloidnog raspona veličina od $1 \mathrm{~nm}$ do $1000 \mathrm{~nm}$. Bilo koja čestica koja je topljiva i koja je u promjeru veća od nekoliko nanometara

\footnotetext{
${ }^{*}$ Autor za dopisivanje: Josip Madunić, mag. biol. mol.

e-pošta: josip.madunic@biol.pmf.hr
}

može se analizirati jednom od tehnika FFF uz pogodne načine detekcije kao što su detekcija ultraljubičasto-vidljivim spektrom (engl. Ultraviolet-visible Spectroscopy, UV/VIS), indeks loma, detekcija višekutnim svjetlosnim raspršenjem (engl. Multi-angle Light Scattering, MALS) itd. ${ }^{3}$

Ovisno o tome razdvajaju li se čestice s obzirom na masu, topljivost, hidrodinamski obujam, električna ili magnetska svojstva, FFF se može podijeliti u pet osnovnih tehnika. Tako su do danas poznate i praktično primijenjene sljedeće tehnike FFF: sedimentacijska (SdFFF), termička (ThFFF), protočna (FIFFF), električna (EIFFF) i magnetska (MgFFF).

Prednost svih tih fleksibilnih analitičkih tehnika FFF je u tome što se razdvajanje molekula analita postiže isključivo interakcijom uzorka s vanjskim ortogonalnim fizičkim poljem umjesto npr., kako je to kod kromatografskih tehnika, interakcijama sa stacionarnom fazom.

Kao što je prikazano na slici 1, separacijsko polje, koje se u tehnici FFF zove kanal, prazan je i inertan, plošno konusni odsječak. Zadržavanje i razdvajanje uzoraka u kanalu ostvaruje se primjenom vanjskog polja koje je okomito na protok u kanalu. Upravo precizna kontrola tog vanjskog polja omogućava razdvajanje tehnikom FFF.

Protok kroz kanal je paraboličan. ${ }^{4}$ Brzina na stijenkama kanala zanemariva je zbog trenja između tekućine i stijenke, no pomicanjem od stijenke kanala brzina raste te je najveća u sredini kanala. ${ }^{5}$ Ako se čestica nađe u pokretnoj fazi koja teče kroz kanal, ona će se kretati između stijenki kanala prema pravilima Brownova gibanja, te će u isto vrijeme ići prema kraju kanala nošena matičnicom.

Brzina čestice ovisi o mjestu paraboličnog protoka, odnosno o mjestu gdje se u to vrijeme čestica nalazi. Na taj se način čestica nasumično giba, pri čemu je to gibanje sporije u blizini stijenki kanala i brže u blizini centra kanala. Čestice za- 


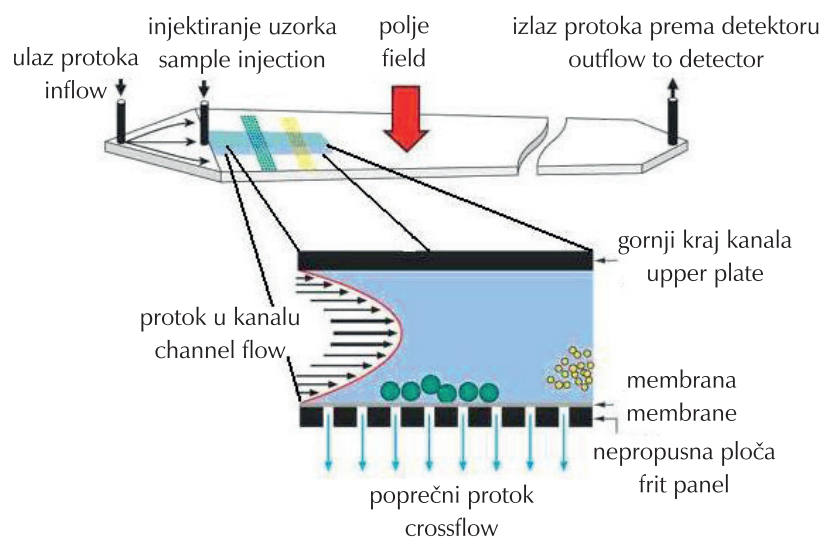

S I i k a 1 - Kanal oblika vrpce s trokutastim krajevima i prikaz paraboličnog protoka kroz kanal FIFFF

F i g. 1 - Ribbonlike channel structure with view of parabolic flow through FIFFF channel

tečene u određenom odsječku protoka kretat će se brzinom koja je jednaka prosječnoj paraboličnoj brzini tog odsječka.

Da bi se postiglo razdvajanje čestica, upotrebljava se vanjsko polje okomito na protok kroz kanal. Polje je definirano kao vanjski utjecaj koji kroz prostor uzrokuje relativan pomak čestica u odnosu na njihovu okolinu. Tako će isto vanjsko polje različito djelovati na različite komponente smjese. Vanjsko polje inducira pomicanje čestica prema vanjskim stijenkama kanala (tzv. akumulacijska stijenka). Istodobno s pomicanjem čestica prema stijenkama kanala događa se difuzija čestica od stijenki kanala. Pri ravnotežnom stanju između tih dviju sila, različite komponente nalaze se pri različitim i jedinstvenim udaljenostima od stijenke kanala. Srednja debljina uravnoteženog sloja neke komponente može se povezati s vremenom zadržavanja komponente i njezinim fizikalno-kemijskim svojstvima. Ona komponenta koja ostvaruje jače interakcije s vanjskim poljem i/ili ima manji difuzijski koeficijent uspostavit će ravnotežno stanje bliže stijenci kanala te će se zbog sporije brzine paraboličnog protoka kroz kanal dulje zadržavati u sustavu tj. vrijeme zadržavanja bit će veće od komponente suprotnih svojstava.

S obzirom na prirodu suprotnih (difuzijskih) sila koje sudjeluju u postizanju ravnotežnog stanja, a time i na vrijeme zadržavanja, razdvajanje čestica možemo opisati s pomoću triju osnovnih mehanizama: normalni (Brownov), sterički i hiperslojni mehanizam (engl. hiperlayer). ${ }^{6}$

Normalnim (Brownovim) mehanizmom (slika 2a) opisuje se gibanje većine submikrometarskih čestica, a razdvajanje se temelji na činjenici da čestice različite mase tvore slojeve različite gustoće. Deblji (širi) slojevi čestica migriraju brže odnosno udaljavaju se više od akumulacijske stijenke, dok gušći (tanji) slojevi migriraju sporije odnosno zadržavaju se bliže akumulacijske stijenke. Debljina slojeva obrnuto je proporcionalna sili primijenjenog vanjskog polja, pri čemu se ta sila obično povećava s povećanjem veličine čestice. Tako manje čestice gotovo uvijek formiraju šire slojeve koji brže migriraju od većih čestica te dospijevaju u područje bržeg paraboličnog protoka, što za posljedicu ima kraće vrijeme zadržavanja. Na čestice promjera većeg od $1 \mu \mathrm{m}$, koje slabo difundiraju od akumulacijske stijenke, ne može se primijeniti Brownov mehanizam, već se primjenjuje sterički mehanizam. Prema njemu veće čestice zbog većeg promjera i veličine stvaraju šire slojeve i dublje prodiru prema centru paraboličnog toka, što naposljetku rezultira bržim ispiranjem odnosno kraćim vremenom zadržavanja (slika $2 b){ }^{7} \mathrm{Na}$ ovaj mehanizmom kretanja utječe fizička (sterička) prepreka u obliku akumulacijske stijenke, pa se on stoga naziva steričkim mehanizmom. Hiperslojni način rada sličan je steričkom načinu, a razlika je u postojanju difuznih sila koje se suprotstavljaju vanjskom polju te uzrokuju difuziju čestice od akumulacijske stijenke. ${ }^{6}$ Te su sile veće što je veći promjer čestice pa se veće čestice podižu više i tako dospijevaju bliže centru protoka, te im je stoga vrijeme zadržavanje kraće od vremena zadržavanja manjih čestica.

Na učinkovitost razdvajanja najviše utječe struktura i geometrija samog kanala. Oblik presjeka određuje profil protoka, a često i smjer polja, brzinu razdvajanja i količinu uzorka koja se može unijeti u sustav da bi se dobili optimalni rezultati. Najčešće upotrebljavan kanal je onaj strukture tanke vrpce. Osim njega poznati su i kružni, kvadratični, cirkularni
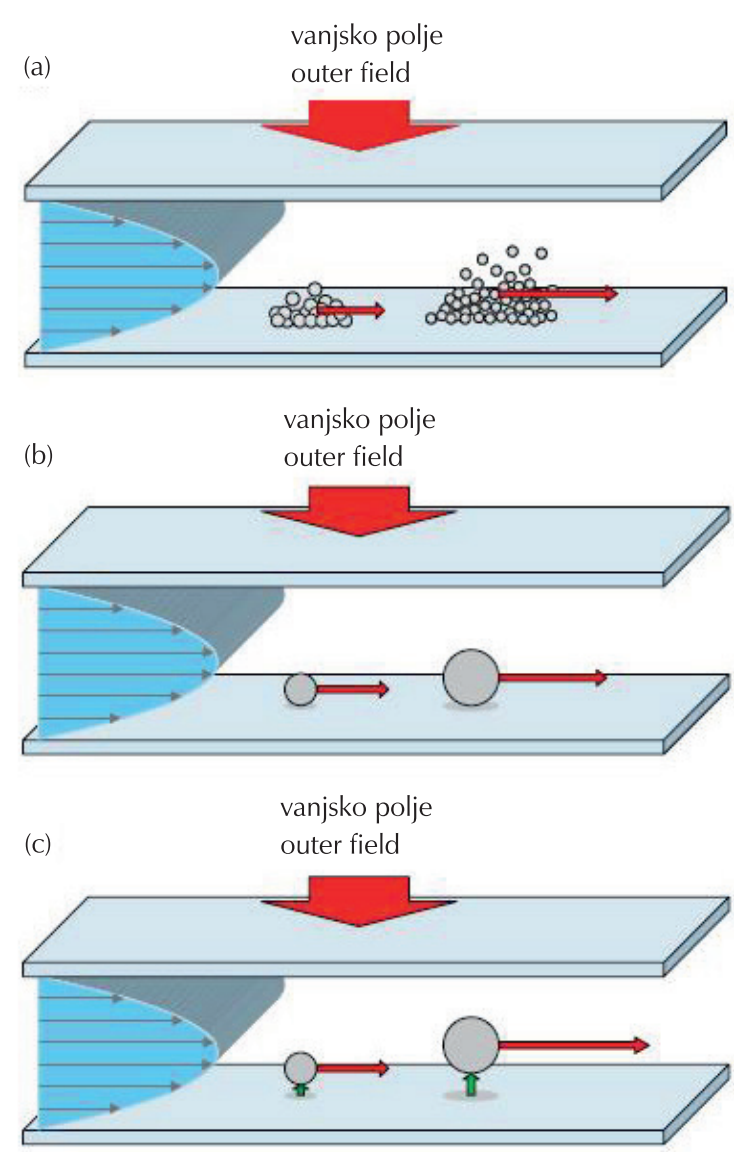

S I i k a 2 - Najčešće primjenjivani načini rada tehnika FFF. Različiti mehanizmi razdvajanja čestica različitih veličina: a) normalni, b) sterički i c) hiperslojni način ${ }^{6}$

F i g. 2 - Most frequently used FFF operation modes. Different mechanisms of separation for particles of different size: a) normal, b) steric and c) hyperlayer mode 6 
$\mathrm{s}$ radijalnim i planarnim poljem te trapezoidni i trokutasti

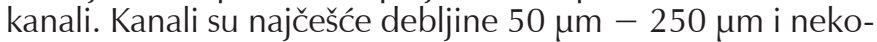
liko centimetara širine. Duž osi protoka kanali mogu biti duljine od nekoliko desetaka centimetara pa sve do jednog metra. Kanal (slika 3) najčešće je konstruiran tako da je izrezan u željenom obliku iz tankog filma, najčešće plastike, koja ujedno predstavlja i tanki držač razmaka (engl. spacer). Držač razmaka zatim se stavlja između dviju jednakih ploča koje moraju biti izrađene od točno određenog materijala, a koji ovisi o primjenjivanom polju npr. za termičku FFF ploče moraju biti napravljene od materijala koji provodi toplinu.

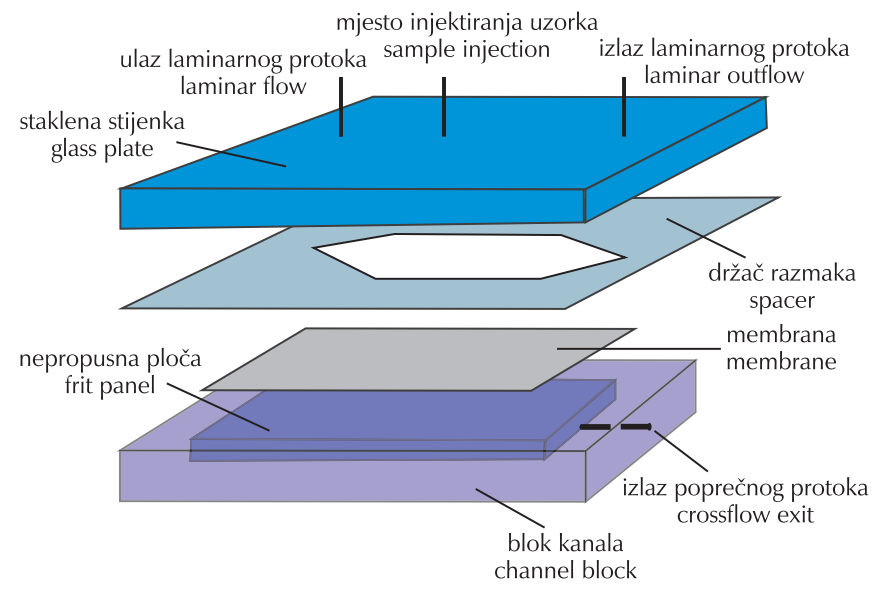

S I i k a 3 - Kanal u asimetričnoj tehnici FIFFF (preuzeto s www.postnova.com)

F i g. 3 - Channel structure in asymmetric FIFFF technique (taken from www.postnova.com)

Prilikom postavljanja eksperimentalnih uvjeta treba voditi računa o dvama glavnim čimbenicima i to o snazi vanjskog polja i protoku. Kod normalnog načina izvođenja analize, povećavanjem snage vanjskog polja pojedine komponente se bolje razdvajaju, no istodobno se produljuje i vrijeme analize. S druge strane, primjena prejakog vanjskog polja može rezultirati gubitkom signala. Protok, koji predstavlja drugi važan čimbenik prilikom analize uzorka, djeluje na taj način da njegovo povećanje obično vodi manjem razlučivanju, ali i skraćenju vremena analize. Osim o snazi vanjskog polja i protoku, prilikom definiranja eksperimentalnih uvjeta treba voditi računa i o temperaturi, jer promjena temperature može katkad rezultirati promjenom razlučivanja i brzine razdvajanja.

Različite tehnike FFF upotrebljavaju različita vanjska polja. Najčešće upotrebljavano vanjsko polje pri analizi proteinskih kompleksa je poprečni protok (tehnika protočne FFF) i temperaturni gradijent (tehnika termičke FFF).

\section{Sedimentacijska tehnika FFF}

Sedimentacijska FFF jednofazna je tehnika razdvajanja koja se najčešće primjenjuje za frakcioniranje i određivanje veličine koloida i čestica veličine od 0,05 $\mu \mathrm{m}$ do $100 \mu \mathrm{m}$, a ponekad i do $500 \mu \mathrm{m} .^{7}$ Vanjsko polje koje se ovdje upo- trebljava je centrifugalno, a razdvajanje se postiže unutar pet minuta upotrebljavajući vrlo kompleksne instrumente. ${ }^{8}$ Prednosti tehnike su široka primjena i visoka efikasnost, a nedostatak je nepostojanje instrumenata koji bi mogli proizvesti dovoljno snažno polje koje bi zadržalo analite male molekulske mase. ${ }^{5}$

\section{Termička tehnika FFF}

Najčešće se primjenjuje za razdvajanje polimera topljivih u organskim otapalima i u manjoj mjeri za razdvajanje čestica. Može se primijeniti na molekule čija je relativna molekularna masa od $10^{4}$ do $10^{7}$. Kao vanjsko polje upotrebljava se temperaturni gradijent. Jedna stijenka grije se pomoću kontroliranog grijača, dok se druga stijenka hladi pomoću recirkulirajućeg hladnjaka. ${ }^{9}$ Temperaturna razlika koja je posljedica grijanja odnosno hlađenja stijenki uzrokuje termičku difuziju uzorka prema akumulacijskoj stijenci (najčešće hladnija stijenka). Vrijeme zadržavanja proporcionalno je razlici temperatura između dviju stijenki multipliciranoj omjerom termičkog difuzijskog koeficijenta prema normalnom difuzijskom koeficijentu.

lako je ova tehnika vrlo korisna, još uvijek nije u potpunosti empirijski objašnjena, te se zbog toga ne može izračunati vrijeme zadržavanja pojedinih komponenti. Razdvajanje molekula temelji se na razlici u molekulskoj masi i sastavu polimera. Za razliku od sedimentacijske FFF, za ovu se tehniku upotrebljavaju mnogo jednostavniji instrumenti.

\section{Protočna tehnika FFF}

U protočnoj tehnici FFF, kao vanjsko polje upotrebljava se drugi, neovisni protok koji ulazi kroz stijenke kanala okomito u odnosu na protok u kanalu. Razdvajanje čestica protokom bez obzira na njihovu masu, naboj, gustoću itd. čini ovu tehniku univerzalnom i primjenjivom za razdvajanje čestica heterogenih smjesa. Ovom se tehnikom mogu razdvojiti čestice veličine od $1 \mathrm{~nm}$ do $50 \mu \mathrm{m} .{ }^{4}$ Zbog svoje jednostavnosti i univerzalnosti predstavlja najčešće primjenjivanu tehniku FFF, a najčešće se njome razdvajaju sintetski polimeri i biološke makromolekule. Tehnika je izuzetno selektivna i ima veliku moć razlučivanja, što pomaže u analizama heterogenosti polimera. Razdvajanje na submikrometarskoj skali temelji se na razlici u hidrodinamičkoj veličini čestica. Glavno ograničenje tehnike je polupropusna membrana koja se upotrebljava kao akumulacijska stijenka, jer ima manju stabilnost i inertnost od akumulacijskih stijenki prisutnih u ostalim tehnikama FFF.

S obzirom na razliku u građi amortizirajuće (engl. depletion) stijenke, protočnu tehniku FFF dijelimo na dvije različite tehnike: simetričnu i asimetričnu protočnu tehniku FFF.

\section{Simetrična protočna tehnika FFF}

Odvajanje u tehnici FIFFF temelji se na razlici u veličini čestica koje se analiziraju. Kod ove tehnike polje predstavlja protok tekućine koji je okomit na protok u kanalu. Kanal koji se najčešće upotrebljava u tehnici FIFFF sastoji se od dvaju blokova s umetnutim nepropusnim pločama (engl. frit panel) između kojih se nalaze držač razmaka (engl. spacer) i membrana, kao što je vidljivo na slici 1. Stijenke kanala su propusne kako bi omogućile prolaz poprečnog protoka u 
smjeru okomitom na protok u kanalu. Membrane sprječavaju da uzorci izađu iz kanala putem poprečnog protoka jer su propusne za pokretnu fazu, ali ne i za uzorak. Polupropusna membrana služi kao akumulacijska stijenka. Ona bi trebala prekrivati cijelu površinu nepropusne ploče, no poželjno je da rubovi membrane prelaze rubove ploča kako bi se membrana mogla pričvrstiti, te na taj način imobilizirati.

Za usmjeravanje protoka najčešća izvedba instrumenata tehnike FIFFF upotrebljava tri para trosmjernih ventila koji preusmjeravaju poprečni protok i protok u kanalu ili oko njega za vrijeme relaksacije uzoraka (slika 4). Kod odvajanja velikih ili teških čestica tehnikom FIFFF, kanal se može postaviti u vertikalan položaj jer se na čestice u vertikalnom položaju osim poprečnim protokom djeluje i gravitacijom. Izmjena brzine protoka u kanalu i poprečnog protoka ima utjecaja na trajanje analize. Povećanje brzine protoka u kanalu, dok se brzina poprečnog drži konstantnom, rezultira smanjenim zadržavanjem čestice i smanjenjem razlučivosti. Kontrola protoka u tehnici FIFFF je otežana u usporedbi s drugim tehnikama FFF zbog neprestanog miješanja dvaju protoka.

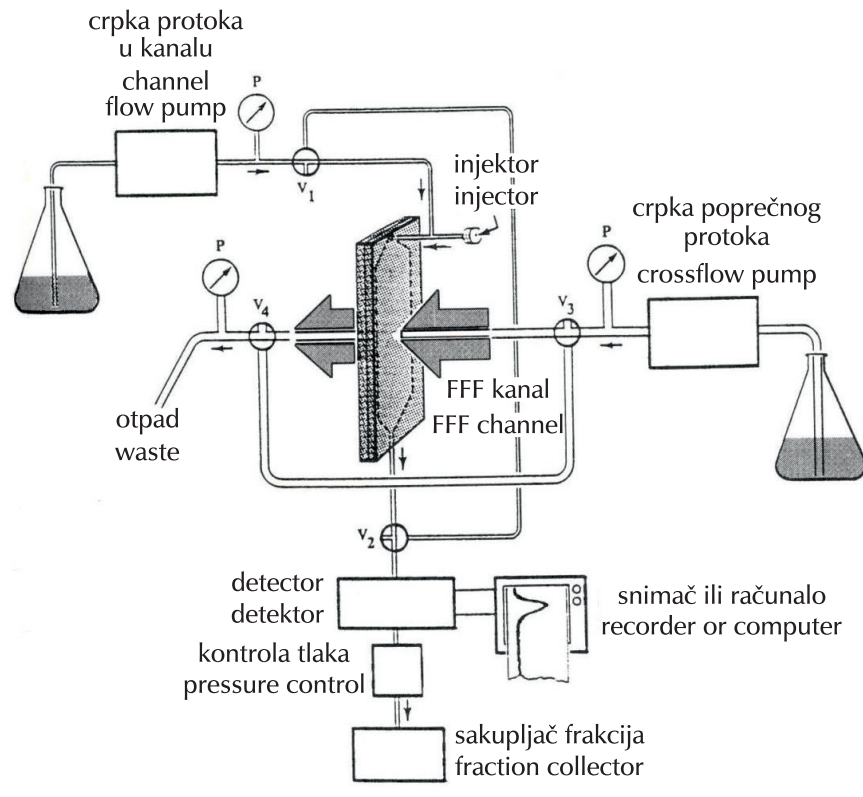

SI i k a 4 - Shema aparature tehnike FIFFF ${ }^{2}$

F i g. 4 - Schematic diagram of FIFFF technique ${ }^{2}$

\section{Asimetrična protočna tehnika FFF}

Ova tehnika ima mnogo sličnosti sa simetričnom tehnikom FIFFF opisanom u prijašnjem odlomku. Važna karakteristika tehnike, a ujedno i razlika između tih dviju vrsta tehnika FIFFF je staklena stijenka koja se upotrebljava kao amortizirajuća (engl. depletion) stijenka. ${ }^{2}$ Ona nije propusna za pokretnu fazu (kao što je slučaj kod simetrične tehnike FIFFF) te omogućava da se tvari u kanalu vide izvana. ${ }^{5}$ Kako amortizirajuća stijenka nije propusna za poprečni protok, on mora ući u kanal zaobilazeći stijenku. Poprečni protok nastaje unutar samog kanala kao rezultat gradijenta tlaka koji se pojavljuje preko membrane. Na taj način brzina poprečnog protoka kroz membranu odgovara gubitku brzine protoka u kanalu kako pokretna faza prolazi kroz kanal. Oblik kanala je obično trapezoidan i širina mu se smanjuje prema izlazu kako bi se brzina protoka u kanalu održala stalnom unatoč njegovu gubitku kroz membranu. Kanal se sastoji od jednog bloka s umetnutom nepropusnom pločom, koja podržava akumulacijsku stijenku (membranu). Taj blok prekriven je drugim blokom koji sadrži amortizirajuću stijenku (staklenu stijenku). Između tih dvaju blokova su porozna membrana i držač razmaka, kao što je vidljivo na slici 3. Asimetrična tehnika FIFFF zahtijeva dvije crpke, jednu za ulazni protok u kanal, a drugu za injektiranje uzorka. Za poprečni protok nije potrebna crpka, jer se on stvara unutar kanala zbog pada tlaka preko membrane. Nakon injektiranja uzorka kod ove tehnike važan je proces fokusiranja, koji se postiže upotrebom tzv. fokusirajućih protoka od kojih jedan dolazi u kanal kroz ulazni dio, a drugi kroz izlazni dio. Važno je znati točku fokusiranja kao i nulto vrijeme (engl. void time) jer se oni primjenjuju za izračunavanje čimbenika zadržavanja, difuzijskih koeficijenata i hidrodinamičkih veličina.

\section{Električna tehnika FFF}

Razdvajanje komponenata u ovoj se tehnici temelji na razlici u veličini i elektroforetskoj pokretljivosti čestica. Nedostatak tehnike je pojava polarizacije elektroda (stijenka kanala) tijekom odvajanja čestica, koje se zbiva zbog orijentacije dipolnih momenata polarnih molekula. Na taj se način smanjuje efektivno električno polje te s njim i efikasnost tehnike. Kako bi se smanjio efekt polarizacije, u novije se vrijeme počelo upotrebljavati izmjenjujuće električno polje kao vanjsko polje. Također, kao dobro rješenje pokazala se i primjena pulsnog električnog polja dobivenog pomoću asimetričnog cikličkog polja. ${ }^{10}$ Glavna primjena tehnike je karakterizacija otopina polimera, koloida, šećera i glina te odvajanje emulzija i bakterija. Tehnika ElFFF se primjenjuje na čestice veličine od 0,01 $\mu \mathrm{m}$ do $10 \mu \mathrm{m}$.

\section{Magnetska tehnika FFF}

Tehnika razdvaja čestice s obzirom na njihova magnetska svojstva i to tako da međusobno djelovanje hidrodinamičkih i magnetskih sila razdvaja čestice kako one putuju duž kanala. ${ }^{11,12}$ Njezina primjena nije još dovoljno istražena, pa tehnika nije u širokoj upotrebi, no jedna od primjena tehnike je npr. razdvajanje i karakterizacija magnetskih nanočestica, ${ }^{13}$ koje se upotrebljavaju u imunospecifičnom označavanju stanica koje se potom razdvajaju na temelju magnetskih svojstava. Tehnika je primjenjiva na čestice nanometarskih i mikrometarskih dimenzija.

\section{Primjene različitih tehnika FFF u analizi kom- pleksnih bioloških uzoraka}

Tehnika SdFFF bila je prva tehnika FFF koja se primjenjivala za odvajanje velikog broja unutarstaničnih organela. Eluirane frakcije sadržavale su mitohondrije, mikrosome, Golgijeve i plazmine membrane. ${ }^{14}$ Tehnika je ujedno dovoljno precizna da odvoji male superzavijene plazmide i DNA $\lambda$-faga bez utjecaja na njihovu konformaciju, te ima najveću moć razdvajanja kod odvajanja bakterija, ${ }^{8}$ pa se zato primjenjuje kod njihove izolacije iz sedimenta ili cirkulirajuće krvi. ${ }^{15}$ Tehnika SdFFF ujedno je primjenjiva i kod analize stanica sisavaca, ${ }_{16}^{16}$ pri čemu frakcionirane stanice zadržavaju svoju vijabilnost i sve karakteristike. ${ }^{17}$ Mogućnost preciznog i 
točnog određivanja molekulske mase i gustoće virusa još je jedna od primjena tehnike SdFFF. U posljednje se vrijeme SdFFF sve više primjenjuje za praćenje specifičnih biofizičkih modifikacija koje nastaju tijekom stanične apoptoze ${ }^{18}$ te kao metoda izbora za praćenje i bolje razumijevanje procesa diferencijacije stanica. ${ }^{19,20}$

Tehnika FIFFF primjenjuje se kako bi se izmjerili različiti difuzijski koeficijenti linearne i cirkularne DNA. Tehnika je primjenjiva kod odvajanja i kvantifikacije tRNA u stanicama rekombinantne bakterije Escherichia coli, te se na taj način dovode u vezu količine proizvedenih proteina s količinama tRNA, kao i sastavom ribosoma. ${ }^{21,22}$ Tehnika FIFFF primjenjuje se i kod odvajanja podjedinica bakterijskih ribosoma kao i različitih tipova stanica od kojih se neke upotrebljavaju u proizvodnji cjepiva. ${ }^{23,24}$

Tehnika GrFFF (gravitacijska tehnika FFF) ima jedinstvenu sposobnost odvajanja živih i mrtvih parazita, pa je osobito primjenljiva u dijagnosticiranju parazitskih infekcija kao i u potvrđivanju intaktnih patogenih bakterija u biološkim uzorcima. ${ }^{25}$ Ova tehnika je prva primijenjena u odvajanju ljudskih eritrocita i može unutar pet minuta odvojiti smjesu stanica raka dojke i normalnih stanica na temelju razlike u gustoći i dielektričnim karakteristikama te je ujedno primjenjiva za odvajanje i kvantificiranje različitih inaktiviranih sojeva bakterije E. coli koji se upotrebljavaju u proizvodnji cjepiva (kao i tehnika FIFFF). ${ }^{24}$ Ti se bakterijski sojevi razlikuju samo po tipu flagela fibrila na staničnoj površini. ${ }^{26}$ Zbog jednostavnosti izvedbe i ekonomičnosti, GrFFF se često primjenjuje u procesima karakterizacije stanica. Tako je razvijena inovativna tehnologija koja se temelji na sprezi GrFFF s fluorescentnim detektorom, a primjenjuje se za određivanje aktivnosti komercijalnih staničnih linija kvasca. ${ }^{27}$

Zbog svojstva razdvajanja velikih čestica (npr. stanica), a da ih pri tome proces razdvajanja ostavlja intaktnima, tehnike FFF mogu se primjenjivati kao alternativne tehnike za sortiranje matičnih stanica pod uvjetom da se matične stanice morfološki razlikuju od ostalih stanica. Prednost tehnika FFF je što se prilikom odvajanja ne potiče diferencijacija stani$\mathrm{ca}^{28}$ kao što je slučaj kod procesa obilježavanja stanica. Još jedna moguća primjena tehnika FFF odvajanje je komponenti kompleksa lipida i DNA kod istraživanja vezanih uz strukturu i aktivnost. Ti su samosastavljajući kompleksi lipida i DNA važni jer se upotrebljavaju kod transfekcije stanica.

Tehnika FFF može pokriti veliki raspon veličina proteina (od
$10^{-4} \mu \mathrm{m}$ do $\left.100 \mu \mathrm{m}\right)$, te je primjenjiva za analizu kompleksnih smjesa koje sadrže proteine različitih veličina. Viskozni i slabo topljivi proteinski agregati predstavljaju problem kod gel-filtracijske tehnike zbog začepljivanja pora u koloni, dok kod tehnike FFF može doći do začepljenja pora na akumulacijskoj stijenci, a obje tehnike se često primjenjuju za razdvajanje agregata, oligomera i monomera proteina. ${ }^{29}$ Jedna od prednosti tehnike FFF je njezina osjetljivost. Uz upotrebu pogodnog detektora (npr. fluorescencijskog ili UV/VIS) mogu se detektirati agregati pri zastupljenosti od samo 0,1 \% uz uvjet da su dobro odijeljeni od drugih čestica. Primjer jednog takvog fraktograma, dobivenog UV/VIS detekcijom, na kojem su dobro odijeljeni protein i proteinski agregati prikazan je na slici 5. Kvantifikacija eluiranog uzorka je ponovljiva, no problem predstavlja mogućnost nastanka agregata prilikom fokusiranja mehanizmom autoasocijacije. Naposljetku, velika prednost tehnike FFF je odsutnost nepokretne faze, pa ne dolazi do interakcija između proteina i nepokretne faze te pri tome nema dodatka organskih otapala (npr. metanol, etanol, acetonitril itd.) u pokretnoj fazi koji mogu uzrokovati strukturne promjene proteina.

Tehnika FIFFF je najčešće primjenjivana tehnika pri analizi proteina i proteinskih kompleksa jer se difuzijski koeficijent može povezati s veličinom i oblikom proteina. Na taj je način moguće pratiti vrlo male promjene u strukturi proteina i proteinskih kompleksa. Mnogo radova objavljeno je na temu primjene tehnike FIFFF na istraživanja proteina iz biljaka. Tako su ispitivana i određivana mjesta vezanja nekih biljnih enzima, ${ }^{30}$ odjeljivani su monomerni i polimerni proteini pšenice $^{31}$ i određivane su molekulske mase raznih proteina iz bilja. ${ }^{32}$ Osim navedenog, FIFFF se primjenjuje i kao metoda kojom se evaluiraju i potvrđuju rezultati dobiveni drugim analitičkim metodama kao što su kromatografija isključenjem po veličini čestica (engl. Size-Exclusion Chromatography, SEC) i metoda rastvaranja (engl. dissolution method). Tako su potvrđeni rezultati dobiveni metodom rastvaranja na uzorcima nereduciranog glutenina iz pšenice. ${ }^{33}$ Osim fluorescencijskog i UV/VIS detektora, jedan od najčešće upotrebljavanih detektora spregnutih s tehnikom FFF je višekutno svjetlosno raspršenje (engl. Multi-Angle Light Scattering, MALS). Jedna od najzanimljivijih primjena sustava FIFFF-MALS je biofizička karakterizacija velikih proteinskih kompleksa ili proteinskih agregata. ${ }^{34,35}$ Taj je sustav primijenjen za proučavanje agregacije proteina priona te je tako nađena veza između veličine i infektivnosti prionskih čestica. ${ }^{36}$ Zbog želje za karakterizacijom cijelih proteina razvijaju se nove, specifične metode. Jedna od takvih

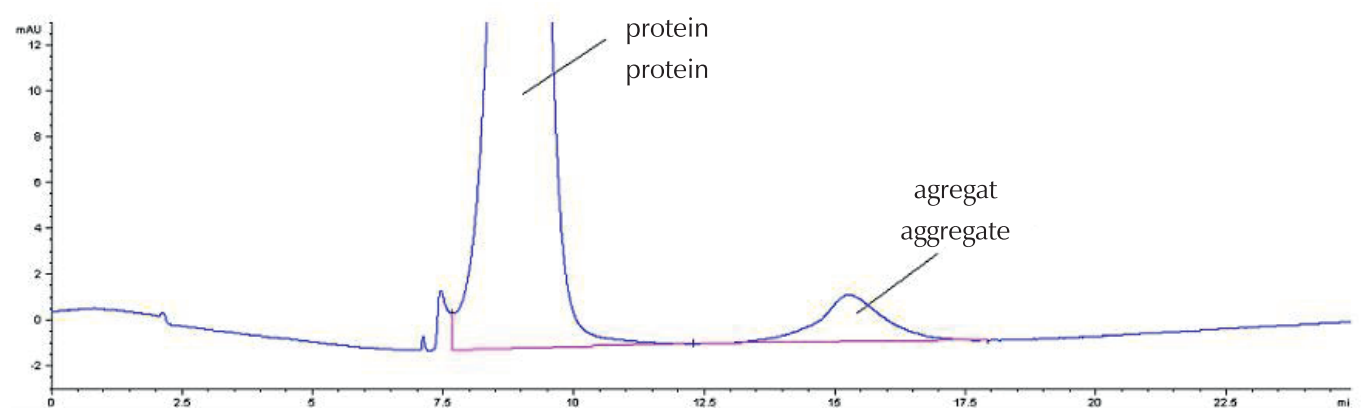

S I i k a 5 -Primjer fraktograma dobivenog UV/VIS detekcijom nakon razdvajanja smjese proteina $i$ agregata protočnim poljem

F i g. 5 - Example of fractogram obtained by UV/VIS detection after protein and aggregate mixture fractionation using field flow fractionation technique 
je i dvodimenzijska tekućinska kromatografija FIFFF, koja je uspješno primijenjena na razdvajanje smjese proteinskih standardâ, ${ }^{37}$ gdje je proučavan učinak grijanja na denaturaciju proteina iz bjelanjka jajeta kao i na cijepanje peptidnih veza u proteinu. ${ }^{38}$

Tehnike FFF mogu se kombinirati sa spektrometrijom masa kako bi se dobile dodatne informacije o konformaciji i identitetu eluiranih frakcija. Primjer takvog sustava vidljiv je na slici $6 .{ }^{39}$ Treba napomenuti da u ovom slučaju FFF služi za predanalitičko odjeljivanje uzoraka (npr. razdvajanje unutarstaničnih vrsta prema veličini čestica) nakon čega slijedi analiza dobivenih frakcija upotrebom naprednih tehnika spektrometrije masa kao što su MALDI/TOFMS za analizu frakcioniranih bakterijskih vrsta, ${ }^{40}$ ESI/TOFMS za dobivanje informacija o kvarternoj strukturi frakcioniranih proteina ${ }^{41} \mathrm{i}$ drugi.

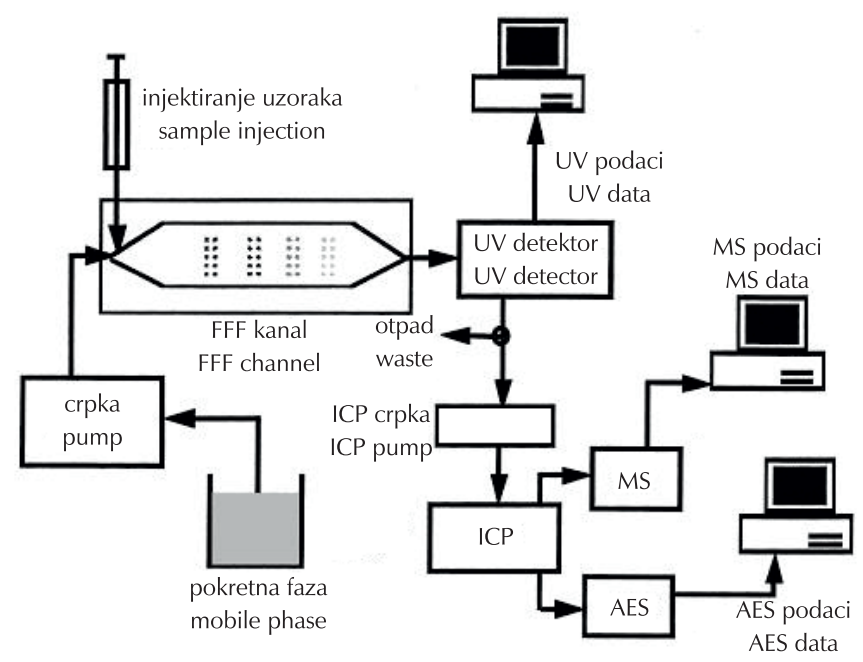

S I i k a 6 - Shematski prikaz sustava MS-FFF ${ }^{38}$

F ig. 6 - Schematic diagram of MS-FFF system ${ }^{38}$

\section{Zaključak}

Današnjim analitičkim metodama teško je analizirati kompleksne uzorke koji mogu sadržavati čestice različitog raspona veličina. Tehnika razdvajanja protočnim poljem je separacijska tehnika otkrivena 60-tih godina koja za osnovicu ima razdvajanje čestica po veličini, odnosno brzini kretanja opisanoj prema Brownovu gibanju. Ima jedinstvenu sposobnost da sa visokom razlučivošću razdvaja čestice preko cijelog koloidnog raspona veličina od 1 do $1000 \mathrm{~nm}$. Jedini preduvjet za razdvajanje je topljivost čestica. Različite varijacije u vrsti upotrijebljenog polja, konfiguracije instrumenata, strukture kanala, načinu izvođenja te varijacije eksperimentalnih uvjeta čine tehniku podobnom za izolaciju i karakterizaciju velikog broja čestica. Sprezanje tehnike sa načinima detekcije poput detekcije ultraljubičasto-vidljivim spektrom, detekcije višekutnim svjetlosnim raspršenjem te spektrometrije masa dodatno svjedoči o primjenjivosti tehnike razdvajanja protočnim poljem u analizi složenih smjesa poput polimera, emulzija, biočestica, složenih proteina i sintetskih polimera.

\section{Popis kratica}

\section{List of acronyms}

AES - atomska emisijska spektroskopija

- atomic emission spectroscopy

EIFFF - električna tehnika FFF

- electrical technique FFF

ESI/TOFMS - ionizacija elektroraspršenjem / masena spektrometrija vremena leta

- electrospray ionization / time-of-flight mass spectrometry

FIFFF - protočna tehnika FFF

- flow technique FFF

FFF - razdvajanje protočnim poljem

- field-flow fractionation

GrFFF - gravitacijska tehnika FFF

- gravitational technique FFF

MALDI - matricom potpomognuta laserska desorpcija i ionizacija

- matrix-assisted laser desorption/ionization

MALS - višekutno svjetlosno raspršenje

- multi-angle light scattering

MgFFF - magnetska tehnika FFF

- magnetic technique FFF

SdFFF - sedimentacijska tehnika FFF

- sedimentation technique FFF

SEC - kromatografija isključenjem po veličini molekula

- size-exclusion chromatography

ThFFF - termička tehnika FFF

- thermal technique FFF

UV/VIS - ultraljubičasto-vidljivi spektar

- ultraviolet-visible spectar

\section{Literatura}

\section{References}

1. J. C. Giddings, A New Separation Concept Based on a Coupling of Concentration and Flow Nonuniformities, Separ. Sci. 1 (1966) 13-125.

2. M. E. Schimpf, K. Caldwell, J. C. Giddings, Field flow fractionation handbook, Wiley-Interscience, New York, 2000.

3. P. Roger, B. Baud, P. Colonna, Characterization of starch polysaccharides by flow field-flow fractionation-multi-angle laser light scattering-differential refractometer index, J. Chromatogr. A 917 (2001) 179-185.

4. 4. M. K. Liu, P. Li, J. C. Giddings, Rapid Protein Separation and Diffusion-Coefficient Measurement by Frit Inlet Flow FieldFlow Fractionation, Protein Sci. 2 (1993) 1520-1531.

5. S. K. Williams, D. Lee, Field-flow fractionation of proteins, polysaccharides, synthetic polymers, and supramolecular assemblies, J. Sep. Sci. 29 (2006) 1720-1732.

6. P. Reschiglian, A. Zattoni, B. Roda, E. Michelini, A. Roda, Fieldflow fractionation and biotechnology, Trends. Biotechnol. 23 (2005) 475-483. 
7. K. D. Caldwell, B. J. Compton, J. C. Giddings, R. J. Olson, Sedimentation Field-Flow Fractionation - a Method for Studying Particulates in Cataractous Lens, Invest. Ophth. Vis. Sci. 25 (1984) 153-159.

8. R. V. Sharma, R. T. Edwards, R. Beckett, Physical Characterization and Quantification of Bacteria by Sedimentation Field-Flow Fractionation, Appl. Environ. Microb. 59 (1993) 1864-1875.

9. G. E. Kassalainen, S. K. R. Williams, Lowering the molecular mass limit of thermal field-flow fractionation for polymer separations, J. Chromatogr. A 988 (2003) 285-295.

10. A. Kantak, M. Srinivas, B. Gale, Characterization of a microscale cyclical electrical field flow fractionation system, Lab. Chip. 6 (2006) 645-654.

11. 11. T. M. Vickrey, J. A. Garciaramirez, Magnetic Field-Flow Fractionation - Theoretical Basis, Separ. Sci. Technol. 15 (1980) 1297-1304.

12. T. C. Schunk, J. Gorse, M. F. Burke, Parameters Affecting Magnetic Field-Flow Fractionation of Metal-Oxide Particles, Separ. Sci. Technol. 19 (1984) 653-666.

13. F. Carpino, L. R. Moore, M. Zborowski, J. J. Chalmers, P. S. Williams, Analysis of magnetic nanoparticles using quadrupole magnetic field-flow fractionation, J. Magn. Magn. Mater. 293 (2005) 546-552.

14. S. M. Mozersky, K. D. Caldwell, S. B. Jones, B. E. Maleeff, R. A. Barford, Sedimentation Field Flow Fractionation of Mitochondrial and Microsomal-Membranes from Corn Roots, Anal. Biochem. 172 (1988) 113-123.

15. F. Bouamrane, N. E. Assidjo, B. Bouteille, M. F. Dreyfuss, M. L. Darde, P. J. P. Cardot, Sedimentation field-flow fractionation application to Toxoplasma gondii separation and purification, J. Pharmaceut. Biomed. 20 (1999) 503-512.

16. E. Assidjo, T. Chianea, M. F. Dreyfuss, P. J. P. Cardot, Validation procedures of sedimentation field-flow fractionation techniques for biological applications, J. Chromatogr. B 709 (1998) 197-207.

17. T. Chianea, P. J. P. Cardot, E. Assidjo, J. Monteil, I. Clarot, P. Krausz, Field- and flow-dependent trapping of red blood cells on polycarbonate accumulation wall in sedimentation fieldflow fractionation, J. Chromatogr. B 734 (1999) 91-99.

18. D. Y. Leger, B. Liagre, P. J. P. Cardot, J. L. Beneytout, S. Battu, Diosgenin dose-dependent apoptosis and differentiation induction in human erythroleukemia cell line and sedimentation field-flow fractionation monitoring, Anal. Biochem. 335 (2004) 267-278.

19. D. Y. Leger, S. Battu, B. Liagre, J. L. Beneytout, P. J. P. Cardot, Megakaryocyte cell sorting from diosgenin-differentiated human erythroleukemia cells by sedimentation field-flow fractionation, Anal. Biochem. 355 (2006) 19-28.

20. G. Begaud-Grimaud, S. Battu, B. Liagre, D. Y. Leger, J. L. Beneytout, P. J. P. Cardot, Pre-apoptotic sub-population cell sorting from diosgenin apoptosis induced 1547 cells by Sedimentation Field-Flow Fractionation - The effect of channel thickness on sorting performance, J. Chromatogr. A 1128 (2006) 194-202.

21. M. Nilsson, P. T. Kallio, J. E. Bailey, L. Bulow, K. G. Wahlund, Expression of Vitreoscilla hemoglobin in Escherichia coli enhances ribosome and tRNA levels: A flow field-flow fractionation study, Biotechnol. Progr. 15 (1999) 158-163.

22. C. Arfvidsson, K. G. Wahlund, Time-minimized determination of ribosome and tRNA levels in bacterial cells using flow fieldflow fractionation, Anal. Biochem. 313 (2003) 76-85.

23. P. Reschiglian, B. Roda, A. Zattoni, B. R. Min, M. H. Moon, High performance, disposable hollow fiber flow field-flow fractionation for bacteria and cells. First application to deactivated Vibrio cholerae, J. Sep. Sci. 25 (2002) 490-498.

24. P. Reschiglian, A. Zattoni, B. Roda, L. Cinque, D. Melucci, B. R. Min, M. H. Moon, Hyperlayer hollow-fiber flow field-flow fractionation of cells, J. Chromatogr. A 985 (2003) 519-529.

25. M. Magliulo, B. Roda, A. Zattoni, E. Michelini, M. Luciani, R. Lelli, P. Reschiglian, A. Roda, An innovative, flow-assisted, noncompetitive chemiluminescent immunclassay for the detection of pathogenic bacteria, Clin. Chem. 52 (2006) 2151-2155.

26. P. Reschiglian, A. Zattoni, B. Roda, S. Casolari, M. H. Moon, J. Lee, J. Jung, K. Rodmalm, G. Cenacchi, Bacteria sorting by field-flow fractionation. Application to whole-cell Escherichia coli vaccine strains, Anal. Chem. 74 (2002) 4895-4904.

27. R. Sanz, M. T. Galceran, L. Puignou, Determination of viable yeast cells by gravitational field-flow fractionation with fluorescence detection, Biotechnol. Prog. 20 (2004) 613-618.

28. C. Lautrette, P. J. P. Cardot, C. Vermot-Desroches, J. Wijdenes, M. O. Jauberteau, S. Battu, Sedimentation field flow fractionation purification of immature neural cells from a human tumor neuroblastoma cell line, J. Chromatogr. B 791 (2003) $149-160$.

29. C. C. Hoppe, L. T. Nguyen, L. E. Kirsch, J. M. Wiencek, Characterization of seed nuclei in glucagon aggregation using light scattering methods and field-flow fractionation, J. Biol. Eng. 2 (2008) 10.

30. J. Fettke, N. Eckermann, S. Poeste, M. Pauly, M. Steup, The glycan substrate of the cytosolic (Pho 2) phosphorylase isozyme from Pisum sativum L.: identification, linkage analysis and subcellular localization, Plant. J. 39 (2004) 933-946.

31. E. Lemelin, T. Aussenac, F. Violleau, L. Salvo, V. Lein, Impact of cultivar and environment on size characteristics of wheat proteins using asymmetrical flow field-flow fractionation and multi-angle laser light scattering, Cereal. Chem. 82 (2005) 28-33.

32. E. Lemelin, G. Branlard, L. Salvo, V. Lein, T. Aussenac, J. Dayde, Breadmaking stability of wheat flours: Relation between mixing properties and molecular weight distribution of polymeric glutenins, J. Cereal. Sci. 42 (2005) 317-326.

33. C. Arfvidsson, K. G. Wahlund, A. C. Eliasson, Direct molecular weight determination in the evaluation of dissolution methods for unreduced glutenin, J. Cereal. Sci. 39 (2004) 1-8.

34. C. Johann, Field-flow fractionation with multiangle light scattering, Pharm. Technol. Eur. 17 (2005) 31-33.

35. T. Arakawa, Philo, J. S., Ejima, D., Sato, H., Tsumoto, K, Aggregation analysis of therapeutic proteins, part 3: Principles and optimization of field-flow fractionation (FFF), Bioprocess International 5 (2007) 52-70.

36. J. R. Silveira, A. G. Hughson, B. Caughey, Fractionation of prion protein aggregates by asymmetrical flow field-flow fractionation, Method. Enzymol. 412 (2006) 21-33.

37. G. Yohannes, S. K. Wiedmer, J. Hiidenhovi, A. Hietanen, T. Hyotylainen, Comprehensive two-dimensional field-flow fractionation-liquid chromatography in the analysis of large molecules, Anal. Chem. 79 (2007) 3091-3098.

38. R. H. Zhu, W. Frankema, Y. L. Huo, W. T. Kok, Studying protein aggregation by programmed flow field-flow fractionation using ceramic hollow fibers, Anal. Chem. 77 (2005) $4581-4586$.

39. S. T. D. J. Chittleborough, J. F. Ranville, F. Shanks, R. Beckett, Soil colloid analysis by Flow Field-Flow Fractionation, $3^{\text {rd }}$ Australian New Zealand Soils Conference, Symposium 4: Emerging soil analytical techniques in the laboratory and the field, Sydney, 2004 
40. P. Reschiglian, A. Zattoni, L. Cinque, B. Roda, F. Dal Piaz, A. Roda, M. H. Moon, B. R. Min, Hollow-fiber flow field-flow fractionation for whole bacteria analysis by matrix-assisted laser desorption/ionization time-of-flight mass spectrometry, Anal. Chem. 76 (2004) 2103-2111.
41. P. Reschiglian, A. Zattoni, B. Roda, L. Cinque, D. Parisi, A. Roda, F. Dal Piaz, M. H. Moon, B. R. Min, On-line hollow-fiber flow field-flow fractionation-electrospray ionization/time-offlight mass spectrometry of intact proteins, Anal. Chem. 77 (2005) 47-56.

\title{
EXTENDED ABSTRACT
}

Field-Flow Fractionation Analysis of Complex Biological Samples

\author{
I. Mijić, ${ }^{\mathrm{a}}$ J. Madunić, ${ }^{\mathrm{b}}{ }^{*}$ S. Marinc, ${ }^{\mathrm{c}}$ and M. Cindrića
}

Normal analytical methods have difficulties when analysing complex samples containing particles of different size. In the 1960s, a new analytical technique was developed, which was able to overcome those difficulties. This new, Field-Flow Fractionation (FFF) technique has been primarily used in the separation of large particles such as macromolecules and colloids. The development and improvement of the FFF technique led to the coupling of the technique with other specific and sensitive analytical methods which resulted in the FFF technique becoming very useful in isolation, separation and analysis of various complex samples, such as powders, emulsions, colloids, geological sediments, biopolymers, complex proteins, polysaccharides, synthetic polymers, and many others. The separation field in the FFF technique is a thin, empty flow chamber called a channel. The structure of the ribbonlike channel with view of the parabolic flow can be seen in Fig. 1. Separation is achieved by the interaction of sample components with an externally generated field, which is applied perpendicularly to the direction of the mobile flow inside the channel. Sample components, which differ in molar mass, size or other properties are pushed by the applied perpendicular field into different velocity regions within the parabolic flow profile of the mobile phase across the channel. The flow has different velocity depending on the position within the channel; the velocity at the walls is zero and it increases towards the centre of the channel. Samples are carried downstream through the channel at different velocities and exit the channel after different retention times. The relative distribution of samples in the parabolic flow determines the separation characteristics. Different operating modes have different types of distributions. The most frequently used mechanisms of FFF separation are listed in Fig. 2. Based on the characteristics of analysed particles and applied outer perpendicular field, FFF techniques can be divided into Sedimentation, Flow, Thermal, Electrical and Magnetic techniques. The FFF techniques versatility, advantages, disadvantages and wide-range application of every specified FFF technique are listed in this review article. Coupling of different FFF techniques with simple or more comprehensive detectors, such as UV/VIS, MALS or mass spectrometer (see Fig. 6) has established the FFF as an efficient and versatile technique. The successful implementation of the FFF technique in the analysis of complex biological samples would influence the future development and direction of the technique's development.

\footnotetext{
${ }^{a}$ Division of Molecular Medicine Rudjer Boskovic Institute Bijenička cesta 54, 10000 Zagreb

${ }^{\mathrm{b}}$ Department of Molecular Biology Faculty of Science, University of Zagreb Horvatovac 102a, 10000 Zagreb

${ }^{\mathrm{c}}$ Kvaliteta, Hospira Zagreb d. o. o.

Prilaz baruna Filipovića 29d, 10000 Zagreb
}

Received January 9, 2013

Accepted June 12, 2013 